УДК $630 * 611(571.63)$

ОПТИМУМ ПРОИЗРАСТАНИЯ ПИХТОВО-ЕЛОВЫХ ЛЕСОВ В ПРИМОРСКОМ КРАЕ

${ }^{1}$ Майорова Л.А., ${ }^{2}$ Петропавловский Б.С.

${ }^{1}$ ФГБУН Тихоокеанский институт географии ДВО РАН, Владивосток, e-mail: mayorova.49@inbox.ru;

${ }^{2}$ ФГБУН Ботанический сад-институт ДВО РАН, Владивосток, е-таil: petrop5@таil.ru

В статье рассматриваются основные районы и оптимальные условия произрастания формации пихтово-еловых лесов (ельников) в Приморском крае. Ареал основной области распространения ельников приурочен к хребту Сихотэ-Алинь и его отрогам. Меридиональное распространение горной страны и разнообразие морфогенетических типов рельефа определяет высокое разнообразие типов леса, почв и микроклимата. Ельники являются основной лесосырьевой базой Приморья, имеют большой лесоресурсный и природоохранный потенциал, занимая более $1 / 3$ лесопокрытой площади края. Почти половина пихтово-еловых лесов охвачена усыханием различной интенсивности. Наиболее активно процесс усыхания взрослого древостоя проявляется на вулканических плато и крутых горных склонах. Для решения задач многоцелевого и неистощимого лесопользования в пихтово-еловых лесах Дальнего Востока коллективом авторов по лесотаксационным материалам лесничеств, лесхозов и заповедников края и картографической информации из карт природы Приморского края создана база данных (БД). На основе анализа сопряженности типов рельефа и типов леса выделены основные высотно-геоморфологические комплексы пихтово-еловых лесов и ареалы распространения. Широкий экологический ареал и высокое разнообразие типов местообитаний пихтовоеловых лесов является главным фактором, определяющим закономерности их географии, потенциальной продуктивности насаждений (классов бонитета) и устойчивости лесных экосистем к современным изменениям климата и антропогенной нагрузки. Для выявления основных климатических факторов среды, определяющих функционирование лесных экосистем данного региона, применялись методы информационной статистики. Методика определения оптимальных условий природной среды для успешного произрастания лесных сообществ позволила выделить оптимумы и пессимумы произрастания ельников в Приморском крае. Современная система лесопользования на Дальнем Востоке далека от совершенства. Полученные научные разработки могут послужить дополнительными критериями для мониторинга лесной растительности Дальнего Востока в условиях изменения климата, выборе путей и методов устойчивого лесопользования, повышения продуктивности и сохранения лесных экосистем в данном регионе.

Ключевые слова: Лесная формация, ельники, тип леса, высотно-геоморфологический комплекс, условия природной среды, оптимум местопроизрастания, бонитет

\title{
OPTIMAL THE GROWTH OF FIR-SPRUCE FORESTS IN THE PRIMORSKY TERRITORY
}

${ }^{1}$ Mayorova L.A., ${ }^{2}$ Petropavlovsky B.S.

${ }^{1}$ Pacific Institute of geography,FEB RAS, Vladivostok,e-mail: mayorova.49@inbox.ru; ${ }^{2}$ Botanical Garden-Institute, FEB RAS, Vladivostok, e-mail: petrop5@mail.ru

The article considers the main areas and optimal growing conditions of the formation of fir-spruce forests (spruce forests) in the Primorsky Territory. The range of the main area of distribution of spruce trees is confined to the SikhoteAlin ridge and its spurs. The meridional distribution of the mountainous country and the variety of morphogenetic types of relief determine the high diversity of forest types, soils and microclimates. Spruce trees are the main forest resource base of Primorye, have a large forest resource and conservation potential, occupying more than $1 / 3$ of the forest covered area of the region. Almost half of the fir-spruce forests are covered by drying of various intensities. The most active process of drying of adult woodland is manifested on volcanic plateaus and steep mountain slopes. To solve the problems of multipurpose and sustainable forest management in the fir-spruce forests of the Far East, a team of authors on forest traction materials of forestries, forest farms and reserves of the region and cartographic information from nature maps of Primorsky Krai created a database (DB). Based on the analysis of the conjugation of relief types and forest types, the main altitude-geomorphological complexes of fir-spruce forests and distribution ranges are identified. The wide ecological range and high diversity of types of habitats of fir-spruce forests is the main factor determining the patterns of their geography, the potential productivity of plantations (bonitet classes) and the resistance of forest ecosystems to modern climate changes and anthropogenic load. Methods of information statistics have been used to identify the main climatic factors that determine the functioning of forest ecosystems in the region. The methodology of determining the optimal conditions of the natural environment for the successful growth of forest communities made it possible to distinguish the optimums and pessimums of the growth of spruce trees in the Primorsky Territory. The modern forest management system in the Far East is far from perfect. The resulting scientific developments could serve as additional criteria for monitoring forest vegetation in the Far East in the face of climate change, choosing ways and means of sustainable forest management, increasing productivity and preserving forest ecosystems in the region.

Keywords: Forest formation, spruce trees, type of forest, high-altitude geomorphological complex, environmental conditions, optimal growth, bonitet

Формация пихтово-еловых лесов (ельников) имеет широкое распространение на Дальнем Востоке, формируя высотный пояс, приуроченный к главному водораз- делу и склонам хребта Сихотэ-Алинь. Формация пихтово-еловых лесов ДВ разделена Ю.И. Манько на приамурско-сихотэ-алиньскую, маньчжурско-южносихотэ-алинь- 
скую и среднесахалинскую географические провинции, отражающие зонально-региональные особенности лесообразовательного процесса [1]. Б.П. Колесников, учитывая неоднородность природных условий ареала формации выделил на территории Приморского края две физико-географические провинции: Средне-Сихотэ-Алинскую (северная часть края) и Южно-Сихотэ-Алинскую (центральная и южная части края), которые соответствуют делению хребта СихотэАлинь на Южный и Средний [2].

Основная лесообразующая порода ельников - ель аянская (Picea ajanensis), содоминант - пихта белокорая (Abies nephrolepis). На севере Приморского края в их насаждениях можно встретить березу плосколистную, каменную, рябину амурскую, лиственницу Комарова, Любарского и единично кедр корейский, а на побережье Японского моря - лиственницу ольгинскую. В южной части ареала (Южно-Сихотэ-Алинская провинция) и по долинам рек западного макросклона Сихотэ-Алиня видовое разнообразие пихтово-еловых лесов возрастает. Наряду с елью аянской в древостоях часто встречается кедр корейский (Pinus koraiensis), дуб монгольский (Quercus mongolica), ясень маньчжурский, липы амурская и Таке, ильмы, березы даурская, желтая. Площадь пихтово-еловых лесов в Приморском крае 3121,3 тыс. га, запасы древесины - 530 млн м ${ }^{3}$ [3].

Целостной картины типологии ельников, продуктивности древостоев и основных причин усыхания древостоев до сих пор нет [4, 5]. С перестройкой системы лесопользования на ДВ и переводом её на коммерческую основу, ситуация с инвентаризацией и лесоустройством лесов ещё более ухудшается [6].

Цель исследования: рассмотреть приуроченность определенных типов леса пихтово-еловой формации к различным высотно-геоморфологическим комплексам, привязку их местообитаний к абсолютным высотам и площадное распространение в Приморском крае. Методами эколого-географического анализа выявить ведущие экологические факторы, влияющие на структуру и динамику ельников и определить районы оптимальных и пессимальных условий среды для произрастания, их связь с продуктивностью древостоев.

\section{Материалы и методы исследования}

Для изучения пихтово-еловых лесов Приморского края были проведены ком- плексные лесоводственно-геоботанические исследования на пробных площадях в районах края, площадная съёмка лесов в верховьях реки Большая Уссурка (Дальнегорский район). На различных элементах рельефа, в различных типах пихтово-елового леса, с различными стадиями усыхания древостоя заложен геоботанический профиль. На основе полевого материала определена возрастная структура и динамика ельников, ход возобновительного процесса, развитие процесса усыхания древостоя. На региональном уровне (Приморский край) проведена выборка лесотаксационной информации по всем лесхозам края различных лет таксации, данных по геоморфологии, климату, почвам и сформирована обширная База данных (БД) «Лесная растительность Приморского края. Пихтово-еловые леса». БД состоит из 1385 точек-площадок $(5 \times 5$ км $)$, на основе географической системы координат привязанных к ареалу. Точка-площадка включает информацию по лесхозу, кварталу, выделу, типу леса, рельефа, почвы, микроклимату, лесотаксационную характеристику древостоя, подроста и пр. [3].

Для анализа наиболее значимых экологических факторов, определяющих распространение ельников в южной части ДВ, были рассмотрены блоки информации БД по климату Приморского края, а также данные по орографии и типам рельефа [7].

Для определения оптимальных и пессимальных типов местообитаний ельников Приморского края и выявления экологического соответствия различных таксонов лесной растительности ведущим факторам среды, составления экологических паспортов леса использованы методы информационной статистики, которые были описаны и апробированы Б.С. Петропавловским в более ранних работах [8]. В качестве показателей среды обитания темнохвойных лесов и отдельных древесных пород взяты суммы активных температур, гидротермические коэффициенты, годовые осадки, январские и июльские температуры воздуха, высота местности над уровнем моря, экспозиция и крутизна склонов. Амплитудам каждого показателя соответствуют шкалы, состоящие из 5-14 градаций. В рамках каждой градации показана преимущественная встречаемость типа леса или лесообразующей породы.

По таблице-матрицы совместной встречаемости градации фактора среды и со- 
стояния таксона (тип леса) и вычислялись коэффициенты наиболее специфичных отношений $(C)$ :

$$
C=\frac{p\left(a_{I} / b_{j}\right)}{p\left(a_{i}\right)},
$$

где числитель - условная вероятность состояния «явления» при данном состоянии фактора (определяется как отношение частоты состояния явления к сумме частот состояний «явления» для данной градации фактора), а знаменатель - априорная вероятность состояния «явления» [9].

Для примера приводим экологический паспорт ели аянской, основной лесообразующей породы (табл. 1) и составленную на его основе карта-схему районов местопроизрастания ельников с указанием сте- пени благоприятности условий природной среды (рис. 1).

\section{Результаты исследования и их обсуждение}

По материалам БД «Пихтово-еловые леса Приморского края» и Справочнику таксатора [10] в данной формации выделено 23 группы типов и типов леса, в т.ч. и промежуточные елово-кедровые леса и еловолиственничные леса. В различных физико-географических провинциях Приморья высотная граница распространения древостоев ельников различна. На севере и в центральных районах края их выдела встречаются в долинах, господствуют на склонах поднимаясь до водораздела, а на юге занимают возвышенные вулканические плато и вершины гор.

Экологический паспорт ели аянской

Таблица 1

\begin{tabular}{|c|c|c|c|c|c|c|c|c|c|c|c|c|c|c|c|}
\hline \multirow[t]{2}{*}{ Факторы среды } & \multicolumn{15}{|c|}{ Градации (коды) факторов природной среды } \\
\hline & 1 & 2 & 3 & 4 & 5 & 6 & 7 & 8 & 9 & 10 & 11 & 12 & 13 & 14 & 15 \\
\hline Сумма активных температур & 1 & + & 0 & + & 0 & 0 & 0 & - & - & - & - & - & - & - & - \\
\hline ГТК (по Селянинову) & 1 & 0 & 0 & 0 & 0 & - & - & - & - & - & - & - & - & - & - \\
\hline Осадки (год) & 0 & 0 & + & + & 1 & 0 & - & - & - & - & - & - & - & - & - \\
\hline Ср. температура в январе & 0 & + & + & + & + & + & 1 & 0 & 0 & 0 & - & - & - & - & - \\
\hline Ср. температура в июле & 1 & 1 & 1 & 0 & 0 & - & - & - & - & - & - & - & - & - & - \\
\hline Тип рельефа (по Ганешину, 1956) & + & 1 & + & 0 & 0 & 1 & 0 & 0 & 0 & 0 & 0 & 0 & 0 & 0 & 0 \\
\hline Абсолютная высота местности (м) & + & 0 & 0 & + & + & + & + & 0 & + & 1 & 1 & 1 & 1 & 0 & - \\
\hline Экспозиция склона & 0 & 0 & 1 & 1 & 1 & 1 & + & 1 & 1 & + & 0 & 0 & + & - & - \\
\hline Крутизна склона & + & + & + & + & + & 1 & - & - & - & - & - & - & - & - & - \\
\hline
\end{tabular}

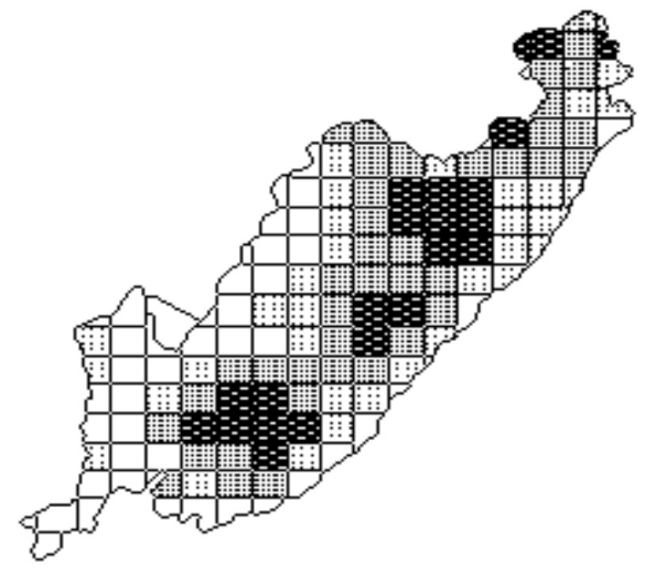

Экологический оптимум произрастания ели аянской САТ (сумма актив. тем-р выше $10^{\circ} \mathrm{C}$ ) - до $1800^{\circ}$; ГТК - более 2,0;

Количество осадков в год - более 800 мм;

$\mathrm{Cp}$. температура января - до $-26^{\circ} \mathrm{C}$;

Ср. температура июня - от +6 до $+200^{\circ} \mathrm{C}$;

Абс. высота местности - свыше 500 м над ур. моря

Экспозиция склонов - все румбы, за искл. Ю и ЮЗ;

Крутизна склонов - свыше $16^{\circ}$.

Рис. 1. Районы оптимальныхх и пессимальных условий среды для произрастания ели. Примечание: Интенсивно выделенные ячейки схемы отражают оптимальные условия местообитаний, разреженные точки-менее оптимальные 
Для объективного отражения экологической и хозяйственной роли темнохвойных лесов, произрастающих на разных элементах рельефа используется вспомогательная единица классификации - геоморфологический комплекс типов леса [1]. Нами выделены четыре высотно-геоморфологических комплекса темнохвойной растительности: высокогорные субальпийские ельники, которые занимают 124852 га площади ареала, среднегорные предсубальпийские ельники (93639 га), ельники горных склонов (1935206 га), ельники долин, шлейфов и пологих склонов (156065 га). А также, переходные еловолиственничные леса (187278 га) и еловокедровые (624260 га).

Карта-схема пихтово-еловых лесов Приморья представлена на рис. 2. Встречаемость (\%) высотно-геоморфологических комплексов отражена в диаграмме (рис. 3).
Большая часть пихтово-еловых и еловолиственничных лесов произрастает на севере и в центральной части Приморского края, в Средне-Сихотэ-Алинской географической провинции темнохвойных лесов. Крупные выдела ельников встречаются на Верхне-Бикинском плато (в верховьях р.р. Самарга, Катен, Чукен, Бикин) и на Светлинском плато (в верховья р.p. Зева, Светловодная, Килоу). Ниже по карте, они образуют компактный массив тайги, который простирается как на восточном макросклоне Сихотэ-Алиня (в верховьях р.p. Кема, Холмогорка, Колумбе), так и большей частью на западном - в верхнем и среднем течении р.p. Арму, Тигринка, Большая Уссурка. Оставшиеся, более мелкие изолированные выдела ельников произрастают на западном макросклоне (по долинам p.p. Журавлевка, Павловка, Малиновка и др.), на главном водоразделе Сихотэ-Алиня и вершинах гор в южной части края.

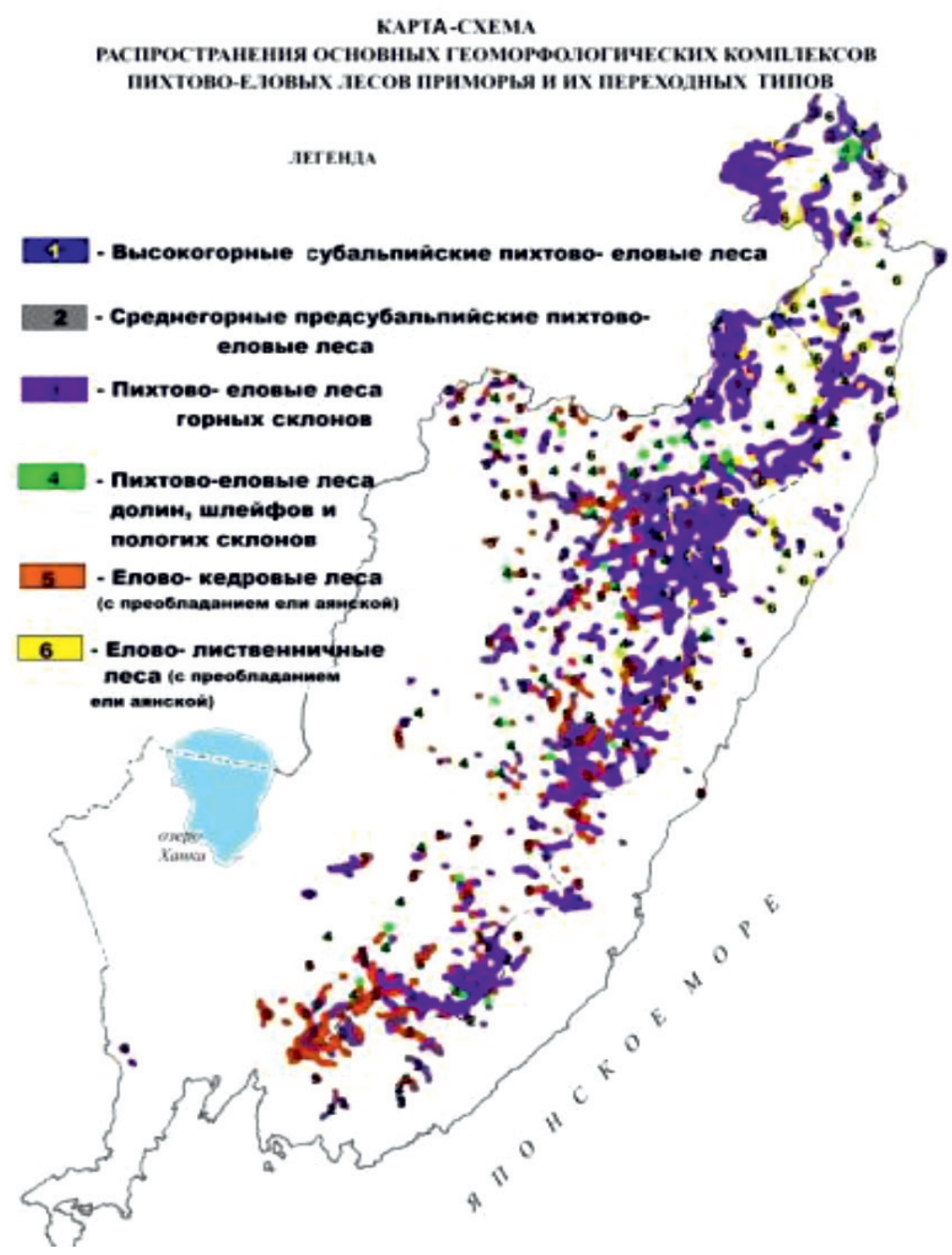

Рис. 2. Ареалы произрастания пихтово-еловых лесов в Приморском крае 


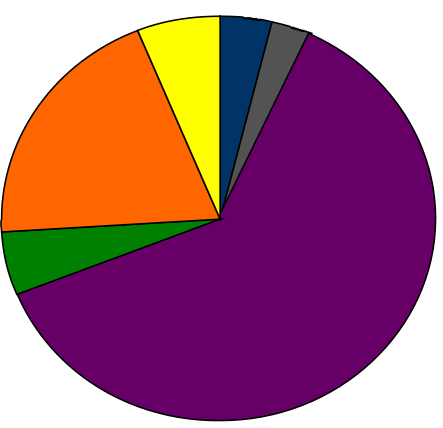

${ }_{1}^{\square} 2^{\square} 3^{\square}{ }^{\square} 5{ }^{\square} 6$
Легенда

1. Высокогорные субальпийские ельники $-4 \%$

2. Среднегорные предсубальпийские ельники - $3 \%$

3. Ельники горных склонов - $62 \%$

4. Ельники долин, шлейфов и пологих склонов $-5 \%$

5. Елово-кедровые леса - $20 \%$

6. Елово-лиственничные леса $-6 \%$

Рис. 3. Встречаемость пихтово-еловых, елово-лиственничных и елово-кедровых лесов в Приморском крае

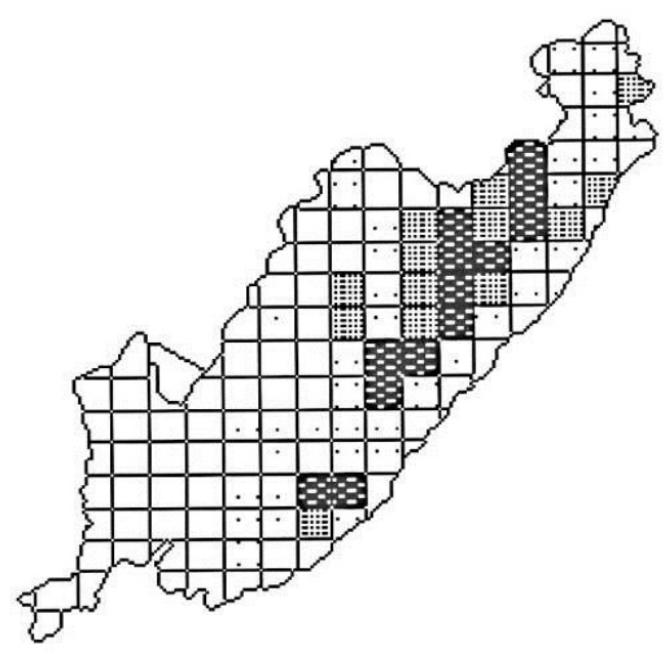

Рис. 4. Районы произрастания ельников зеленомошных (Ез, Емз)

Геоморфологический комплекс пихтово-еловых лесов горных склонов широко распространен в Приморском крае. Сюда входят ельники зеленомошные, мелкотравно-зеленомошные, ельники разнотравномелкопапоротниковые и кустарниково-разнотравные. Типы этой группы занимают около $85-90 \%$ всей площади пихтово-еловых лесов [4].

Приводим краткое описание ельника зеленомошного на ключевом участке «Нечет» (Сихотэ-Алинский заповедник). Абс. высота 850 м над ур. м, склон северо-западной экспозиции, крутизна $15-20^{\circ}$. I ярус 5Е4П1К. По ели таксац. показатели: ср. Д38 см, ср. Н - 28 м, ср. возраст - 200 лет. Сомкнутость крон $-1,0$. Запас $-300 \mathrm{~m}^{3} / \mathrm{ra}$. Бонитет - II. Подрост из ели и кедра, густой,

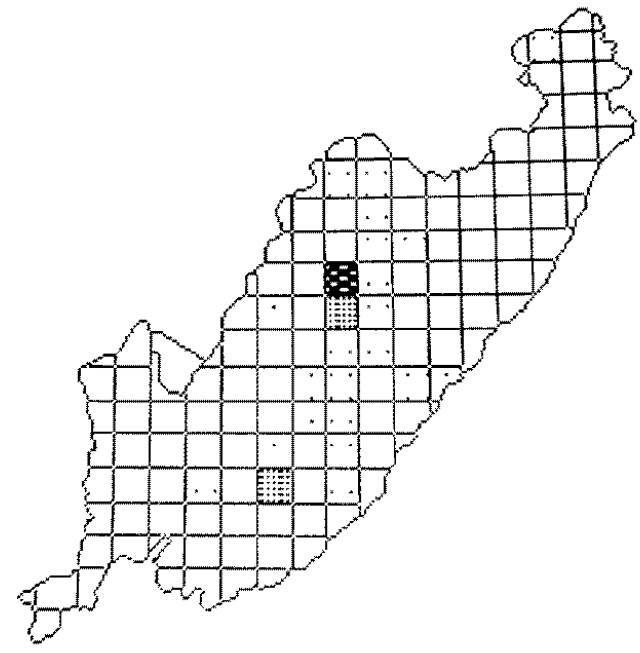

Рис. 5. Районы произрастания ельников кустарниково-разнотравных (Екр)

разновозрастный. Подлесок не выражен, единично - спирея березолистная. Мхи сплошь, травостой - лесное мелкотравье (проективное покрытие - 10\%).

Экологические паспорта широко распространённых ельников-зеленомошных и менее представленного - ельника кустарниково-разнотравного, наглядно показывают их распространение внутри ареала, оптимумы и пессимумы произрастания на территории Приморского края (рис. 4, 5).

Сложная мозаика климатопов, обусловленная экспозицией, крутизной склонов и степенью удаленности от побережья Японского моря вносит свои коррективы в их распространение [11]. Оптимальные климатические условия для произрастания ельников зеленомошных, чаще отмечаются 
на главном водоразделе Сихотэ-Алиня и прилегающих плато с высотами более 700 м над ур. моря, на крутых склонах различных экспозиций, на севере и в центральных районах. Климат здесь прохладный, суммы активных температур не выше $1600^{\circ} \mathrm{C}$, количество осадков - до 800 мм/год. Оптимум произрастания ельников кустарниково-разнотравных отмечается на западном макросклоне Сихотэ-Алиня и в южной части Приморского края. Они произрастают в нижнем поясе гор (до 800 м над ур. моря), на более пологих склонах. Климат местообитаний более теплый и влажный с суммами активных температур от 1600 до $2200^{\circ}$ и количеством осадков более 800 мм/год [12].

Запасы древесины в субальпийских и предсубальпийских ельниках, елово-лиственничных лесах низкие - (80-160 м³/га). Ельники горных склонов и елово-кедровые леса - самые продуктивные, имеют средние запасы - (160-240 м³/га) и выше среднего
(240-320 м³/га). Ельники долин характеризуются низкими запасами из-за рубок и лесных пожаров.

Важным показателем благоприятности условий среды соответствующим типам леса, выступает их потенциальная продуктивность. Встречаемость классов бонитета насаждений в различных геоморфологических комплексах пихтово-еловых лесов отражена на рис. 6.

Пихтово-еловые леса Приморского края, в массе характеризуются IV классом бонитета. Почти 90\% лесов, а это в основном ельники горных склонов и елово-кедровые леса, имеют среднюю продуктивность (III и IV классы бонитета). Древостои I класса бонитета в таксационных описаниях лесхозов отмечены единично, поэтому авторами в анализ не включены. Небольшая доля древостоев II класса бонитета (2\%), характерна только для ельников горных склонов и елово-кедровых лесов.
Бонитеты древостоев ельников су бальпийских

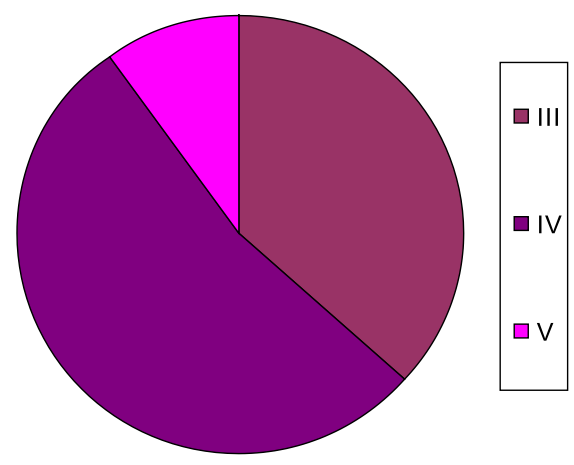

Бонитеты древостоев елово-кедровых лесов

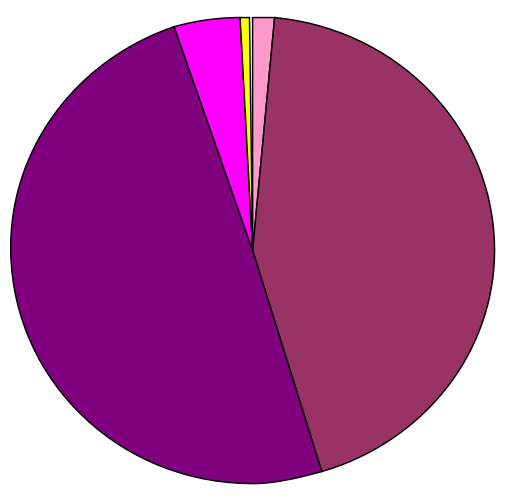

Бонитеты древостоев ельников горных склонов

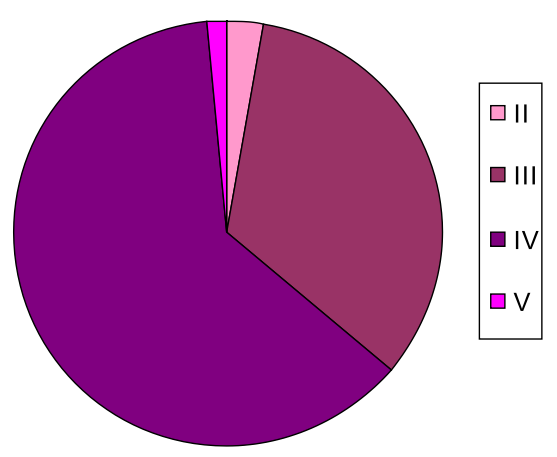

Бонитеты древостоев ельников долинных

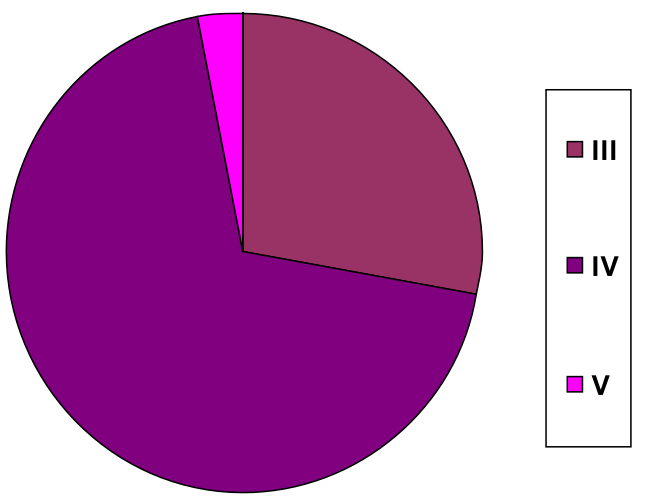

Рис. 6. Классы бонитета древостоев высотно-геоморфологических комплексов пихтово-еловых лесов Приморья 
Как видно из диаграммы (рис. 6), к низкопродуктивным (V, Va класса бонитета) можно отнести $8 \%$ древостоев пихтово-еловых лесов. Это в основном, субальпийские, предсубальпийские ельники и елово-лиственничные леса. Но, на самых неблагоприятных местопроизрастаниях данную продуктивность могут давать и ельники горных склонов.

\section{Заключение}

Как показывают натурные наблюдения на пробных площадях и анализ БД «Лесная растительность Приморского края. Пихтово-еловые леса» разнообразие ландшафтной структуры ареала пихтово-еловых лесов определяет их типологию, структуру и продуктивность. Выделены 23 группы типов леса, объединенные в 4 высотно-геоморфологических комплекса темнохвойной растительности и представлена карта-схема их ареалов на территории Приморья. На основе расчета количественных связей типов пихтово-елового леса с факторами природной среды выявлены наиболее значимые экологические факторы, определяющие их структуру и динамику. Отмечены оптимумы и пессимумы местообитаний ельников, площадное распространение, потенциальная продуктивность и встречаемость классов бонитета древостоев в различных высотно-геоморфологических комплексах.

Результаты исследований и представленные карта-схемы распространения пихтово-еловых лесов в Приморском крае могут быть, в первую очередь использованы для выделения эталонных лесов, районов создания лесных культур, лесопитомников, для мониторинга процесса усыхания пихтово-еловых древостоев и возможного запрета промышленных рубок в наиболее уязвимых типах леса. Применение обширного материала из БД по пихтово-еловым лесам, его временная дифференциация с использованием математических и картографических методов даёт возможность более полно восстанавливать и детализировать ход лесообразовательного и лесовосстановительного процесса в пихтово-еловой формации данного региона, а также прогнозировать изменения структуры и динамики лесов при изменении тепло- и влагообеспеченности их местообитаний.

\section{Список литературы / References}

1. Манько Ю.И. Возникновение и становление генетической лесной типологии // Лесоведение. 2013. № 6. С. 40-57.

Manko Iu.I. The emergence and development of genetic forest typology // Lesovedenie. 2013. No. 6. P. 40-57 (in Russian).
2. Колесников Б.П. Кедровые леса Дальнего Востока. М.-Л.: Изд-во АН СССР, 1956. 261 с.

Kolesnikov B.P. Cedar woods of the Far East. M.-L.: Izdvo AN SSSR, 1956. 261 p. (in Russian).

3. Майорова Л.А. Пихтово-еловые леса Приморского края (эколого-географический анализ): автореф. дис. ... канд. биол. наук. Уссурийск, 2012. 27 с.

Mayorova L.A. The fir-spruce forests of Primorsky Krai (ecological-geographical analysis): avtoref. ... kand. biol. nauk. Ussuriysk, 2012. 27 p. (in Russian).

4. Розенберг В.А., Васильев Н.Г. Леса Приморского края // Леса СССР. М., 1969. Т. 4. С. 621-667.

Rozenberg V.A., Vasilyev N.G. Forests of Primorsky Krai // Lesa SSSR. M., 1969. T. 4. P. 621-667 (in Russian).

5. Манько Ю.И., Гладкова Г.А., Бутовец Г.Н. К изучению естественной динамики пихтово-еловых лесов Центрального Сихотэ-Алиня // Вестник КрасГАУ. 2011. № 2(63). C. $121-126$.

Manko Yu.I., Gladkova G.A., Butovets G.N. To studying the fir-spruce forest natural dynamics in the Central Sikhote-Alin // Vestnik KrasGAU. 2011. No. 2(63). P. 121-126 (in Russian).

6. Выводцев Н.В. Государственная инвентаризация лесов на Дальнем Востоке // Проблемы устойчивого управления лесами Сибири и Дальнего Востока: материалы Всерос. конф. Хабаровск: Из-во ФБУ «ДальНИИЛХ», 2014. С. 20-23.

Vyvodsev N.V. State Forest Inventory in the Far East // Problems of sustainable forest management in Siberia and the Far East: materials Vseros. conf. Khabarovsk: FBU «DalNIILH», 2014. P. 20-23 (in Russian).

7. Майорова Л.А., Петропавловский Б.С. Выявление оптимальных условий природной среды характерных для произрастания пихтово-еловых лесов в Приморском крае // Охрана и рациональное использование лесных ресурсов: матер. X междунар. форума. Благовещенск: Изд-во Дальневост. гос. аграрного ун-та, 2019. С. 100-104.

Mayorova L.A, Petropavlovsky B.S. Identification of optimum conditions of the environment for growth of fir-spruce the forests in Primorsky territory // Forest resources protection and rational use: Materials of the X International Forum. Blagoveshchensk: DGAU, 2019. P. 100-104 (in Russian).

8. Петропавловский Б.С. Типы леса - основа лесных кадастров // Труды Никитского ботанического сада. 2016. T. 143. C. 156-163.

Petropavlovsky B.S. Forests types - the basis of forests inventories // Trudy Nikitskogo botanicheskogo sada. 2016. V. 143. P. 156-163 (in Russian).

9. Semkin B.I. Elementary theory of similarities and its use in biology and geography. Pattern Recognition and Image Analysis: Allen Press Inc. (United States). 2012. Vol. 22. P. 92-98.

10. Справочник таксатора / Составитель Н.В. Ефимов. Хабаровск: В/о «Лесопроект», Дальневосточный трест, 1955. $133 \mathrm{c}$.

Spravochnik taksatora / Sostavitel N.V. Efimov. Khabarovsk: V/o 'Lesoproekt', Far East Trest, 1955. 133 p. (in Russian).

11. Урусов В.М., Варченко Л.И. Мозаика климатопов как условие выживания дубравного на юге Дальнего Востока // Проблемы ботаники Южной Сибири и Монголии: матлы XVII Междунар. научно-практической конф. Барнаул: Из-во Алтайского университета, 2019. С. 397-401.

Urusov V.M., Varchenko L.I. Mosaic of climatops as a condition for the survival of the oak forest complex in the south of the Far East // Problems of botany of South Siberia and Mongolia: Sbornik XVII mezhdunarodnoy nauchno-prakticheskoy konferentsii. Barnaul, 2019. P. 397-401 (in Russian).

12. Майорова Л.А. Основные климатипы местообитаний пихтово-еловых лесов Приморья // Исследование и конструирование ландшафтов Дальнего Востока и Сибири / Под ред. В.М. Урусова. Владивосток: Дальнаука, 2005. Вып. 6. С. 176-195.

Mayorova L.A. Osnovnye klimatipi mestoobitaniy pikhtovo-elovykh lesov Primorskogo kraia// Issledovaniie i kostryirovaniie landshaftov Dalnego Vostoka i Sibiri. Vladivostok: Dalnauca. 2005. V. 6. P. 176-195 (in Russian). 